\title{
Evaluation of PCR electrospray-ionization mass spectrometry for rapid molecular diagnosis of bovine mastitis
}

\author{
Vincent Perreten, ${ }^{* 1}$ Andrea Endimiani, ${ }^{* 2}$ Andreas Thomann, ${ }^{*}$ Juliette R. K. Wipf, ${ }^{*}$ Alexandra Rossano, ${ }^{*}$

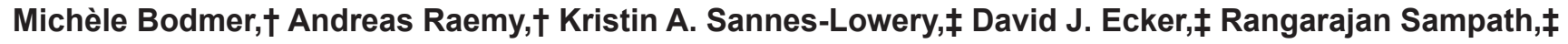 \\ and Robert A. Bonomoß\# \\ *Institute of Veterinary Bacteriology, and \\ †Clinic for Ruminants, Vetsuisse Faculty, University of Bern, Bern, Switzerland \\ łlbis Biosciences, an Abbott Company, 2251 Faraday Ave., Carlsbad, CA 92008 \\ $\S$ Departments of Medicine, Pharmacology, and Molecular Biology and Microbiology, Case Western Reserve University School of Medicine, \\ 10900 Euclid Ave., Cleveland, OH 44106 \\ \#Research Service, Louis Stokes Cleveland Department of Veterans Affairs Medical Center, 10701 East Blvd., Cleveland, OH 44106
}

\begin{abstract}
Bovine mastitis, an inflammatory disease of the mammary gland, is one of the most costly diseases affecting the dairy industry. The treatment and prevention of this disease is linked heavily to the use of antibiotics in agriculture and early detection of the primary pathogen is essential to control the disease. Milk samples ( $\mathrm{n}=$ 67) from cows suffering from mastitis were analyzed for the presence of pathogens using PCR electrosprayionization mass spectrometry (PCR/ESI-MS) and were compared with standard culture diagnostic methods. Concurrent identification of the primary mastitis pathogens was obtained for $64 \%$ of the tested milk samples, whereas divergent results were obtained for $27 \%$ of the samples. The PCR/ESI-MS failed to identify some of the primary pathogens in $18 \%$ of the samples, but identified other pathogens as well as microorganisms in samples that were negative by culture. The PCR/ ESI-MS identified bacteria to the species level as well as yeasts and molds in samples that contained a mixed bacterial culture (9\%). The sensitivity of the PCR/ESIMS for the most common pathogens ranged from 57.1 to $100 \%$ and the specificity ranged from 69.8 to $100 \%$ using culture as gold standard. The PCR/ESI-MS also revealed the presence of the methicillin-resistant gene mecA in $16.2 \%$ of the milk samples, which correlated with the simultaneous detection of staphylococci including Staphylococcus aureus. We demonstrated that PCR/ESI-MS, a more rapid diagnostic platform compared with bacterial culture, has the significant potential to serve as an important screening method in the diagnosis of bovine clinical mastitis and has the
\end{abstract}

Received September 5, 2012.

Accepted February 22, 2013.

${ }^{1}$ Corresponding author: vincent.perreten@vetsuisse.unibe.ch

${ }^{2}$ Present address: Institute for Infectious Diseases, University of Bern, Friedbühlstrasse 51, Postfach 61, CH-3010 Bern, Switzerland. capacity to be used in infection control programs for both subclinical and clinical disease.

Key words: milk, detection, dairy cow, method

\section{INTRODUCTION}

Bovine mastitis, an inflammatory and infectious disorder of the udder tissue in cows, often occurs in response to bacterial invasion, and less frequently to invasion by molds, yeasts, Prototheca, and viruses (Wellenberg et al., 2002; Rakesh et al., 2006; Möller et al., 2007; Zadoks et al., 2011). The economic effect of bovine mastitis is significant, and in some cases nearly $10 \%$ of total milk production is unusable (Seegers et al., 2003; Halasa et al., 2007; Hogeveen et al., 2011). The diagnosis of clinical bovine mastitis is based on the abnormal appearance of milk, visible and or palpatory changes in the udder, and elevated SCC (Ruegg, 2003). Subclinical infections, however, are economically more problematic and clinical signs are not obvious, as the milk appears normal despite an increased SCC. Microbiological examination of the milk is necessary to determine the cause of the infection and allow veterinarians to use appropriate therapeutic measures. To date, cultures of the pathogens and microscopy remain the most common approaches to identify the pathogens in milk. However, the samples may contain a large variety of microorganisms, making the identification of the primary pathogens very difficult. Additionally, mastitis may be caused by slow-growing bacteria, such as $M y$ coplasma spp., which require special growth medium, thus delaying diagnosis. To overcome these problems, PCR-based methods have been developed; they are frequently restricted to a limited number of pathogens, however (Viguier et al., 2009; Ajitkumar et al., 2012).

Multiple PCR followed by electrospray-ionization mass spectrometry (PCR/ESI-MS) has been developed to rapidly detect nearly all known pathogens, 
including those causing bovine mastitis, as well as some important antibiotic-resistant genes. This technology consists of DNA amplification by PCR of specific regions of ribosomal and conserved house-keeping genes, as well as some antibiotic-resistant genes, which are electrosprayed into a time-of-flight MS for molecular weight measurement. The mass of each amplicon is translated into base composition for organism and antibiotic-resistant gene identification (see Ecker et al., 2008, and Wolk et al., 2012, for reviews of the methodology, flow scheme, and laboratory application). This technology has also found applications in human clinical diagnostics (Arciola et al., 2011; Wolk et al., 2012). The objective of this pilot study was to assess whether PCR/ESI-MS can be a useful technology for the rapid identification of bovine mastitis-causing pathogens compared with standard milk cultures. Earlier and more precise detection of the pathogens would help to identify risk factors for bovine mastitis and aid in the therapeutic strategy, as well as in the development of appropriate screening and control programs.

\section{MATERIALS AND METHODS}

\section{Milk Sampling}

Milk samples $(10 \mathrm{~mL})$ were prospectively collected aseptically from cows affected by clinical (changes in secretion or changes in the consistency of the mammary gland) and subclinical mastitis (SCC $>150,000$ cells / $\mathrm{mL}$ ) and from healthy cows ( $\mathrm{SCC}<150,000$ cells $/ \mathrm{mL}$ ) in Switzerland. Cows were selected according to their last individual SCC test day as measured using a Fossomatic 500 cell counter (Foss, Hillerød, Denmark), and a California Mastitis Test was performed after forestripping as described previously (Barnum and Newbould, 1961). A threshold of $\geq 800,000$ to $5,000,000$ cells $/ \mathrm{mL}$, providing a sensitivity of $72 \%$ and a specificity of $64 \%$ for detecting IMI, was used (Ruegg 2003). Eight milliliters of milk were used directly for bacteriological analysis and the remaining $2 \mathrm{~mL}$ were shipped overseas at room temperature without preservatives for subsequent DNA extraction and PCR/ESI-MS analyses.

\section{Bacteria Isolation and Identification}

Milk samples were centrifuged at $590 \times g$ for $10 \mathrm{~min}$ at room temperature. Cultivating for the common milk pathogens, one loop-full $(10 \mu \mathrm{L})$ of the resulting pellet and supernatant was plated directly onto tryptone soy agar plates containing 5\% sheep blood (TSA-SB; BD, Franklin Lakes, NJ) and onto selective bromothymolblue lactose (Brolac; bioMérieux SA, Marcy-l'Étoile, France) agar plates. The TSA-SB plates were incubated with $5 \% \mathrm{CO}_{2}$ for $24 \mathrm{~h}$ for the detection of microaerophilic bacteria, such as Histophilus somni, and for another $24 \mathrm{~h}$ at $37^{\circ} \mathrm{C}$ under aerobic conditions to support the growth of strict aerobic bacteria. Brolac agar plates were incubated under aerobic conditions at $37^{\circ} \mathrm{C}$ for 24 to $48 \mathrm{~h}$ for the detection of lactose-positive or negative bacteria and the specific growth of yeast. Additionally, samples suspected of containing Aspergillus spp. were cultivated on Sabouraud Agar (Oxoid, Basingstoke, UK); those suspected of containing Mycoplasma bovis were cultivated on specific Mycoplasma agar (Oxoid) at $37^{\circ} \mathrm{C}$ for 2 to $5 \mathrm{~d}$.

Staphylococcus aureus was identified on TSA-SB agar plates based on the production of an $\alpha$ - and $\beta$-(double) hemolysis. $\alpha$-Hemolytic Staph. aureus were identified using chromogenic agars SA select (Bio-Rad, Hercules, CA) and Staph. aureus ID agar (bioMérieux). Other species of staphylococci (non-aureus Staphylococcus spp., including CNS) were not further identified. Streptococci, enterocococci, and lactococci were identified using a biochemical scheme described previously (Guélat-Brechbuehl et al., 2010). Enterobacteriaceae (e.g., Escherichia coli) were identified by microscopy, lactose fermentation, and indole production assays. Corynebacterium bovis, Arcanobacterium pyogenes, yeasts, and Prothoteca were identified by microscopy or phenotypic reactions using Vitek Compact 2 (bioMérieux).

Anaerobic bacteria were identified by direct microscopy of the milk pellet and strict anaerobic growth on TSA-SB. Aspergillus spp. were identified by microscopic morphology and by specific coloration appearance on Sabouraud agar. Mycoplasma bovis was identified by PCR (Subramaniam et al., 1998). Plates grown with a layer or with more than 3 microorganisms displaying different morphology were considered as containing a mixture of bacteria, which were not further identified by culture. A method of semiquantification [few ( $>30$ colonies), moderate (30-100), or many (>100)] was used to report the relative numbers of bacteria present in the milk samples (Washington, 1996).

\section{PCR/ESI-MS}

The DNA for PCR/ESI-MS was extracted from $1 \mathrm{~mL}$ of each milk samples using a method that combines beadbeating cell lysis with a magnetic-bead base extraction (Abbott, Des Plaines, IL). Briefly, the milk was mixed with proteinase K, and 20\% SDS solution was mixed with the extraction control in a tube containing $1.5 \mathrm{~g}$ of 0.2 -mm yttrium-stabilized zirconium oxide beads. The mixture was then homogenized in a tissue homogenizer (Precellys 24, Bioamerica Inc., Miami, FL) at 6,200 rpm for $90 \mathrm{~s}$ three times, with 5 -s intervals between events. Each homogenized lysate was incubated at $56^{\circ} \mathrm{C}$ 
for $15 \mathrm{~min}$ and then centrifuged for $3 \mathrm{~min}$ at $16,000 \times$ $g$ in a bench-top microcentrifuge. Next, DNA from the lysate was isolated using a magnetic particle processor (Kingfisher Flex, Thermo Scientific, Waltham, MA). The lysate was transferred to a 24 deep-well plate along with lysis buffer and magnetic particles. Each lysate mixture was incubated for $16.5 \mathrm{~min}$ in the lysis buffer at $56^{\circ} \mathrm{C}$. Specimens were then washed once in wash buffer 1 , and 3 times in wash buffer 2 (1-min incubation for each wash step). The magnetic beads were then dried for $3 \mathrm{~min}$ at $65^{\circ} \mathrm{C}$, and nucleic acids were eluted into $250 \mu \mathrm{L}$ of DNA/RNA-free water by incubating the magnetic particles at $65^{\circ} \mathrm{C}$ for $3 \mathrm{~min}$. The PCR/ESIMS analyses were performed on the PLEX-ID using the PLEX-ID BAC Detection assay (Cat. No. 05N13-62, Abbott) for the detection and identification of more than 3,400 species of bacteria, 40 species of Candida, and 4 antibiotic-resistant markers (mecA, vanA, vanB, and $\left.b l a_{K P C}\right)$ direct from the sample. All groups of bacteria, including intracellular organisms such as Mycoplasma, Chlamydia, and Rickettsia and hard to culture or nonculturable organisms, could be detected by this assay. Analysis was performed using the software version 2.6.052 (Ibis Biosciences; Ecker et al., 2008). The PLEX-ID BAC Detection assay has a DNA calibrant in each reaction, which allows for semiquantitative analysis (Hofstadler et al., 2005). By comparing the relative intensity of the target DNA to that of the calibrant, the relative concentration of target DNA initially present is determined (Ecker et al., 2008).

The PLEX-ID BAC assay uses signal thresholds (cutoffs) designed to limit reporting of irreproducible detections. Cutoffs are applied to 2 measurements. The first, termed the level, is an indication of the amount of the amplicon present in the sample reported as genome equivalents (GE) per well. This is calculated with reference to the internal calibrant and has been described previously (Hofstadler et al., 2005). The linear range for reporting these levels is between $0.1 \times$ and $10 \times$ the levels of internal controls in the assay, which, in the case of the fungal assay, represents a working range of $\sim 2 \mathrm{GE} /$ well to $200 \mathrm{GE} /$ well. The second is the quality score (Q-score), which represents a relative measure of the strength of the data supporting identification. The Q-Score is a rating between 0 (low) and 1 (high), based on several parameters. Parameters include an indicator of how well the hypothesized organisms, as a group, represent the observed data; an indicator of how significant the contribution of a single organism is to the solution; the fraction of missed detections, which represents the percentage of primers for a detected organism that should have produced known base count compositions, but did not; and, finally, the percentage of primers for a detected organism for which no known data exists within the PLEX-ID system. The Q-score cutoffs are designed to prevent reporting (positive identification) of specific organisms when the information obtained is not sufficient to confidently resolve the organism's identity. For the PLEX-ID BAC assay, a Q-score $\geq$ 0.85 is considered a reportable result. The specificity and sensitivity of the PCR/ESI-MS method was determined using culture as gold standard.

\section{RESULTS}

A total of 67 milk samples originating from 21 cows with clinical mastitis, 34 cows with subclinical mastitis, and 12 healthy cows were analyzed using both standard bacteriology and PCR/ESI-MS analysis. Overall, a $64.1 \%$ agreement was observed between the 2 methods, with results concurrent with both methods for 43 milk samples (Table 1, samples 1-43). Among them, PCR/ ESI-MS and cultures generated the exactly same results for 18 milk samples (Table 1, samples 1-18). In the other 24 milk samples with concurrent results, PCR/ ESI-MS identified additional microorganisms in 18 milk samples compared with culture (Table 1, samples 19-36), whereas culture revealed additional microorganisms in only 3 milk samples compared with PCR/ ESI-MS (Table 1, samples 37-39). Besides a concurrent identification of 1 type of microorganism in 4 milk samples, PCR/ESI-MS and cultures both identified additional but different organisms (Table 1, samples 40-43). Both methods revealed the presence of CNS in 12 milk samples: Streptococcus uberis (7 samples), Streptococcus dysgalactiae (1 sample), Staph. aureus (4 samples), C. bovis (3 samples), Mycoplasma spp. (2 samples), A. pyogenes (3 samples), Enterococcus spp. (4 samples), Enterobacteriaceae (2 samples), as well as the absence of detectable microorganisms in 4 samples (Table 1, samples 15-18). Specific identification of the pathogens could not be made by culture or by PCR/ ESI-MS for 2 milk samples, but both methods identified a mixture of different bacteria in one sample and a mixture of anaerobic bacteria in the other (Table 1, samples 10 and 14). Otherwise, PCR/ESI-MS allowed identification of bacteria to the species level, as well as yeast and fungi.

Indeed, in 6 additional samples containing a mixture of bacteria $(8.8 \%)$ consisting of more than 3 different microorganisms, which are routinely not further identified individually, PCR/ESI-MS allowed identification of CNS (Staphylococcus sciuri, Staphylococcus vitulinus, Staphylococcus xylosus, Staphylococcus equorum) in all samples and also yeasts (Candida albicans), molds (Penicillium marneffei), Pseudomonas spp., Acineto- 


Standard Number Genomes/

Number Genomes/

Q-score ${ }^{2}$

Identification

Agreement Broader

\begin{tabular}{|c|c|c|c|c|}
\hline & & & & \\
\hline 1 & M0439 & Clinical & Staphylococcus aureus & $<30$ \\
\hline 2 & M0671 & Subclinical & Staph. aureus & $>100$ \\
\hline 3 & M0478 & Clinical & Streptococcus uberis & $>100$ \\
\hline 4 & M0479 & Clinical & Strep. uberis & $>100$ \\
\hline 5 & JM0501 & Clinical & Strep. uberis & $30-100$ \\
\hline 6 & M2716 & Subclinical & Strep. uberis & $>100$ \\
\hline 7 & M0625 & Control & Corynebacterium bovis & $30-100$ \\
\hline 8 & M2745 & Clinical & Mycoplasma spp. & \\
\hline 9 & M2744 & Clinical & $\begin{array}{l}\text { Arcanobacterium pyogenes } \\
\text { Mycoplasma spp. }\end{array}$ & $>100$ \\
\hline 10 & M2727 & Subclinical & $\begin{array}{l}\text { A. pyogenes } \\
\text { Mix of anaerobes }\end{array}$ & $\begin{array}{l}>100 \\
>100\end{array}$ \\
\hline 11 & M2746 & Subclinical & Enterococcus spp. & $30-100$ \\
\hline 12 & M2741 & Subclinical & CNS & $<30$ \\
\hline 13 & M2786 & Subclinical & CNS & $30-100$ \\
\hline 14 & M0472 & Clinical & Mix of bacteria & $<30$ \\
\hline 15 & M0667 & Subclinical & No growth & \\
\hline 16 & M0680 & Subclinical & No growth & \\
\hline 17 & M0682 & Control & No growth & \\
\hline 18 & M0689 & Subclinical & No growth & \\
\hline 19 & M0421 & Subclinical & CNS & $<30$ \\
\hline
\end{tabular}

M0424 Subclinical CNS

$21 \quad$ M0481 Subclinical CNS

C. bovis

22 M0624 Control CNS

$23 \quad$ M2778 Subclinical CNS

1 Staph. aureus ${ }^{3}$

$852 \quad 0.87 \quad$ Strep.

$149 \quad 1 \quad$ Strep. uberis ${ }^{3}$

$226 \quad 1 \quad$ Strep. uberis ${ }^{3}$

297

1

Strep. uberi
C. bovis

$70.92 \quad \begin{aligned} & \text { Mycoplasma spp. } \\ & \text { Arcanobacterium spp. }\end{aligned}$

$1,344 \quad 0.92 \quad$ Mycoplasma spp.

190.96 Arcanobacterium spp.

spp.

$\begin{array}{lll}74 & 0.99 & \text { Enterococcus faecalis } \\ & & \\ 60 & 0.99 & \text { Staphylococcus xylosus }\end{array}$

$\begin{array}{ll}0.99 & \text { Staphylococcus xy } \\ 1 & \text { Staph. xylosus } \\ \end{array}$

$\begin{array}{ccl}7 & 1 & m e c A \\ \mathrm{NA}^{4} & \text { NA } & \text { Unidentified complex mixture }\end{array}$

NA NA Negative

NA Negative

NA NA Negative

$\begin{array}{lll}79 & 1 & \text { Staphylococcus saprophyticus } \\ & \end{array}$

entification

0.87 Gemella hemolysans ${ }^{5}$

Candida parapsilosis ${ }^{3}$

mecA

0.96 Staphylococcus warneri/Staphylococcus haemolyticus Yes

$0.98 \quad$ C. bovis ${ }^{3}$

0.97 Phaeosphaeria nodorum/Phaeosphaeria sp. Sn 48-1 ${ }^{5}$

1 Staph

0.89 Pseudomonas syringae ${ }^{5}$

0.99 Staph. xylosus

mecA

None

None

$\begin{array}{ll}\text { Yes } & \text { None } \\ \text { Yes } & \text { None }\end{array}$

Yes None

$\begin{array}{ll}\text { Yes } & \text { None } \\ \text { Yes } & \text { None }\end{array}$

$\begin{array}{ll}\text { Yes } & \text { None } \\ \text { Yes } & \text { None }\end{array}$

$\begin{array}{ll}\text { Yes } & \text { None } \\ \text { Yes } & \text { None }\end{array}$

Streptococcus spp. ${ }^{3}$

$\begin{array}{llll}24 & \text { M0626 } & \text { Control } & \begin{array}{l}\text { CNS } \\ \text { Mix of bacteria }\end{array} \\ 25 & \text { M0426 } & \text { Clinical } & \begin{array}{l}\text { Staph. sciuri } \\ \text { Mix of bacteria }\end{array} \\ 26 & \text { M2750 } & \text { Subclinical } & \text { Staph. aureus } \\ 27 & \text { M0463 } & \text { Clinical } & \text { Strep. uberis } \\ 28 & \text { M2810 } & \text { Subclinical } & \text { Strep. uberis }\end{array}$

Staph. xylosus

Yes None

Yes Non

None PCR/ESI-MS

None

None

None

None

None

PCR/ESI-MS

PCR/ESI-MS

PCR/ESI-MS

PCR/ESI-MS

0.88 Pseudomonas fluorescens

0.86 Pseudomonas. entomophila/Pseudomonas. putida

1 Staph. sciuri/Staph. vitulinus ${ }^{3}$

0.86 Enterococcus faecium

0.95 Candida famata ${ }^{3}$

$1 \quad$ mecA

0.99 Staph. aureus ${ }^{3}$

Additional firmicutes

$0.97 \quad$ Strep. uberis

0.86 Staphylococcus spp. ${ }^{3}$

$0.92 \quad$ Strep. uberis ${ }^{3}$

PCR/ESI-MS

PCR/ESI-MS 
Table 1 (Continued). List of samples that generated concurrent results when analyzed with standard culture identification and PCR electrospray-ionization mass spectrometry (PCR/ESI-MS)

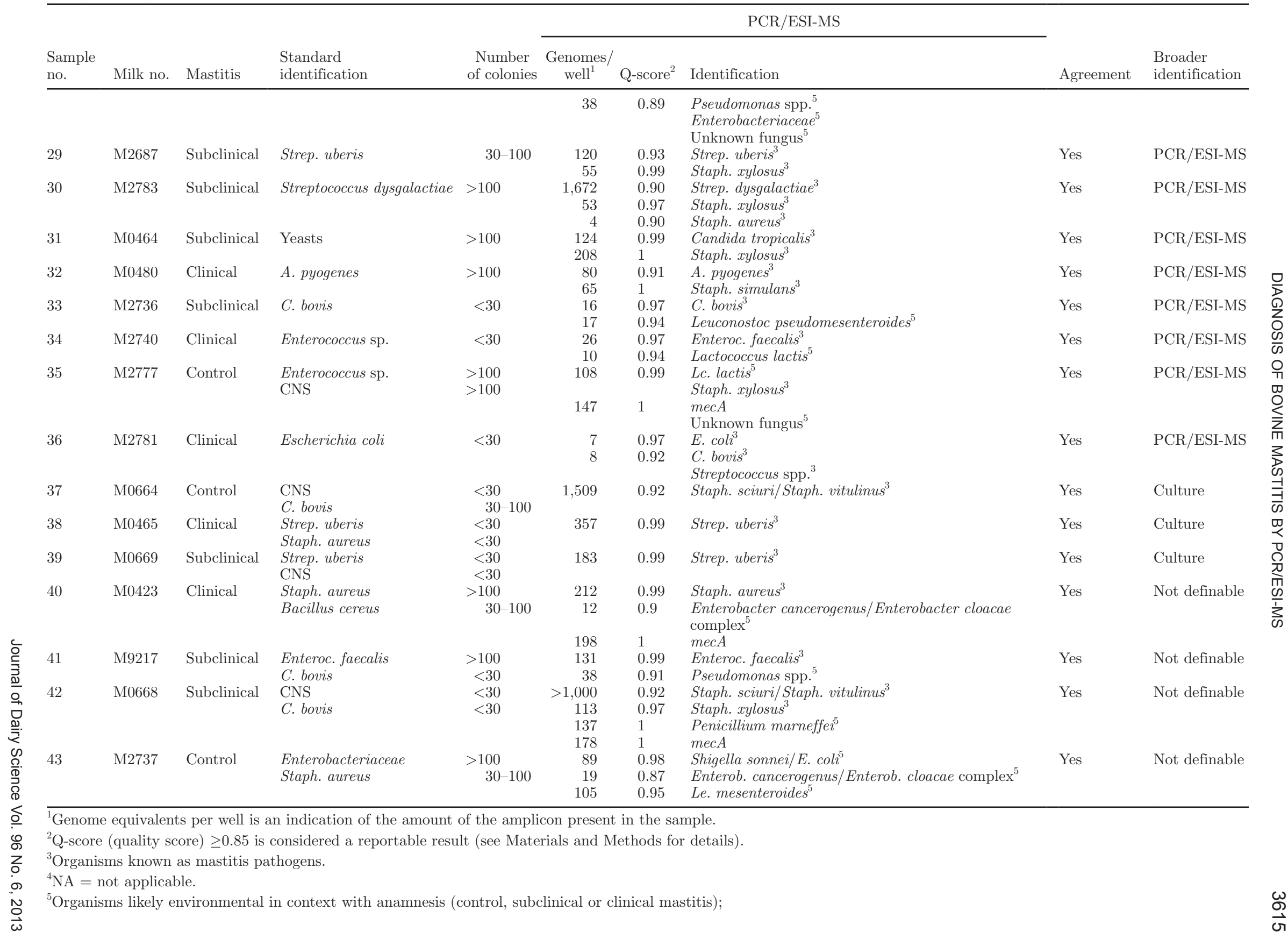


bacter spp. Chryseobacterium indologenes, and enterococci (Enterococcus saccharolyticus and Enterococcus faecalis; Table 2, samples 44-49). However, PCR/ESIMS failed to identify the complete flora in such highly contaminated samples. For those samples, PCR/ESIMS identified only up to 2 different microorganisms (Table 2, samples 45-49), except for 1 sample where more than 3 microorganisms (Staph. xylosus, Enteroc. faecalis, Acinetobacter johnsonii, and C. albicans) were identified using PCR/ESI-MS (Table 2, sample 44).

Divergent results between the culture and the PCR/ ESI-MS methods were obtained for 18 milk samples (27.9\%; Table 3). In this instance, PCR/ESI-MS failed to identify one of the primary pathogens in $17.9 \%$ of the samples, but it identified microorganisms in samples that were negative by culture $(9 \%)$ as well as other pathogens $(3 \%)$. In one sample, PCR/ESI-MS identified Pseudomonas spp. instead of C. bovis (Table 3 , sample 50). The PCR/ESI-MS only identified the facultative anaerobic bacteria Enterococcus spp. and Psychrobacter spp. in 1 milk sample that also contained a mix of strictly anaerobic bacteria (Table 3, sample 51). The PCR/ESI-MS failed to identify yeasts in 1 sample, but revealed the presence of Moraxella/Acinetobacter spp. and Staph. xylosus instead (Table 3, sample 52). The PCR/ESI-MS identified Lactococcus lactis in 2 milk samples, and did not detect the primary mastitis pathogens Staph. aureus and Strep. uberis in these samples (Table 3, samples 53 and 54). In 2 samples containing Strep. uberis, PCR/ESI-MS revealed the presence of Leuconostoc mesenteroides and fungi in 1 sample, and Aspergillus amstelodami, Staph. aureus, and unknown bacteria in the other sample (Table 3, samples 55 and 56). In 5 samples, PCR/ESI-MS remained negative, whereas bacteria such as CNS, E. coli, Strep. dysgalactiae, and yeasts could be cultivated on the agar plates (Table 3, samples 58-61). On the other hand, PCR/ESI-MS identified fungi as well as bacteria (Staph. xylosus, Staph. haemolyticus, Staph. vitulinus, Janthinobacterium lividum, Erwinia tasmaniensis/rhapontici) in 6 milk samples that remained negative on agar plates (Table 3, samples 62-67).

The mecA gene was detected in 11 samples (16.4\%) and was always associated with the presence of staphylococci. In one sample, mecA was associated with the presence of Staph. aureus (Table 1, sample 40), otherwise it was linked to CNS (Table 1, samples 13, 19, 23, 25, 35, and 42; Table 2, samples 44, 45, and 46; Table 3 , sample 67).

The relative quantity of microorganisms growing on the culture media and the genomic quantification obtained by PCR/ESI-MS differed from sample to sample and no significant quantitative association could be made between both methods (Tables 1-3). Overall,

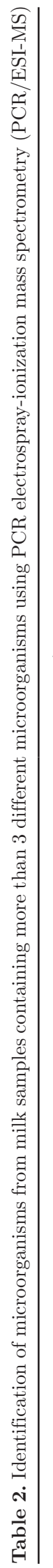

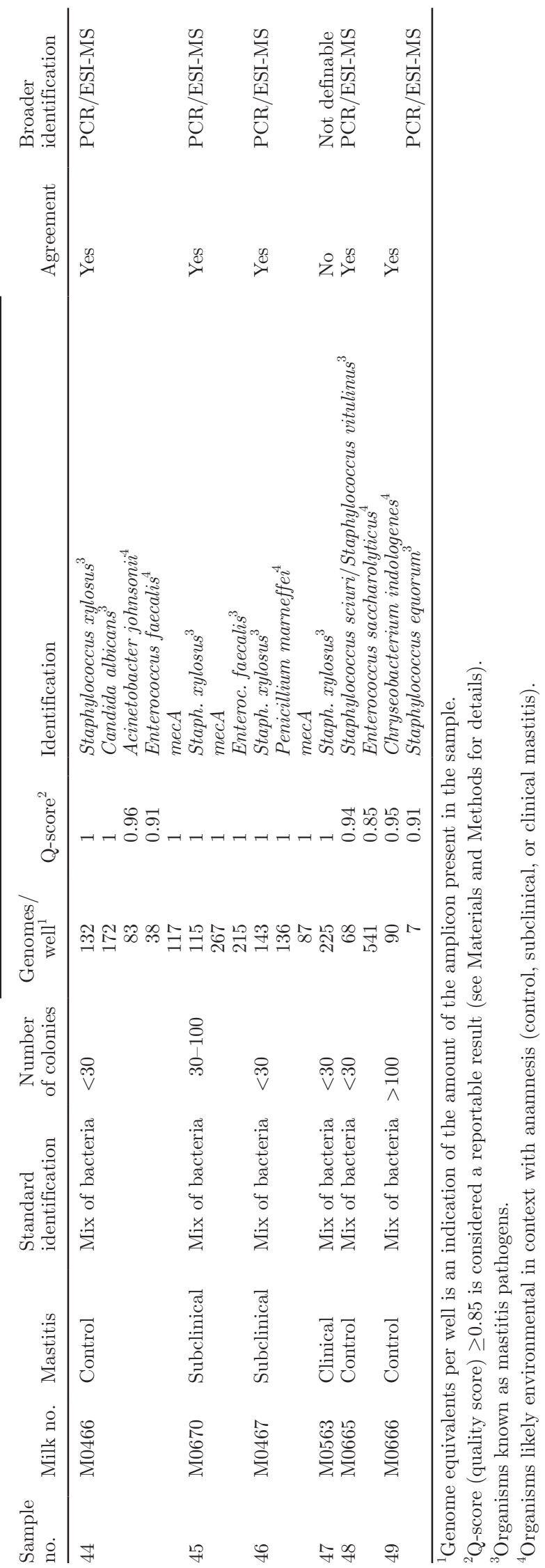


Table 3. List of results showing divergence between the culture method and PCR electrospray-ionization mass spectrometry (PCR/ESI-MS)

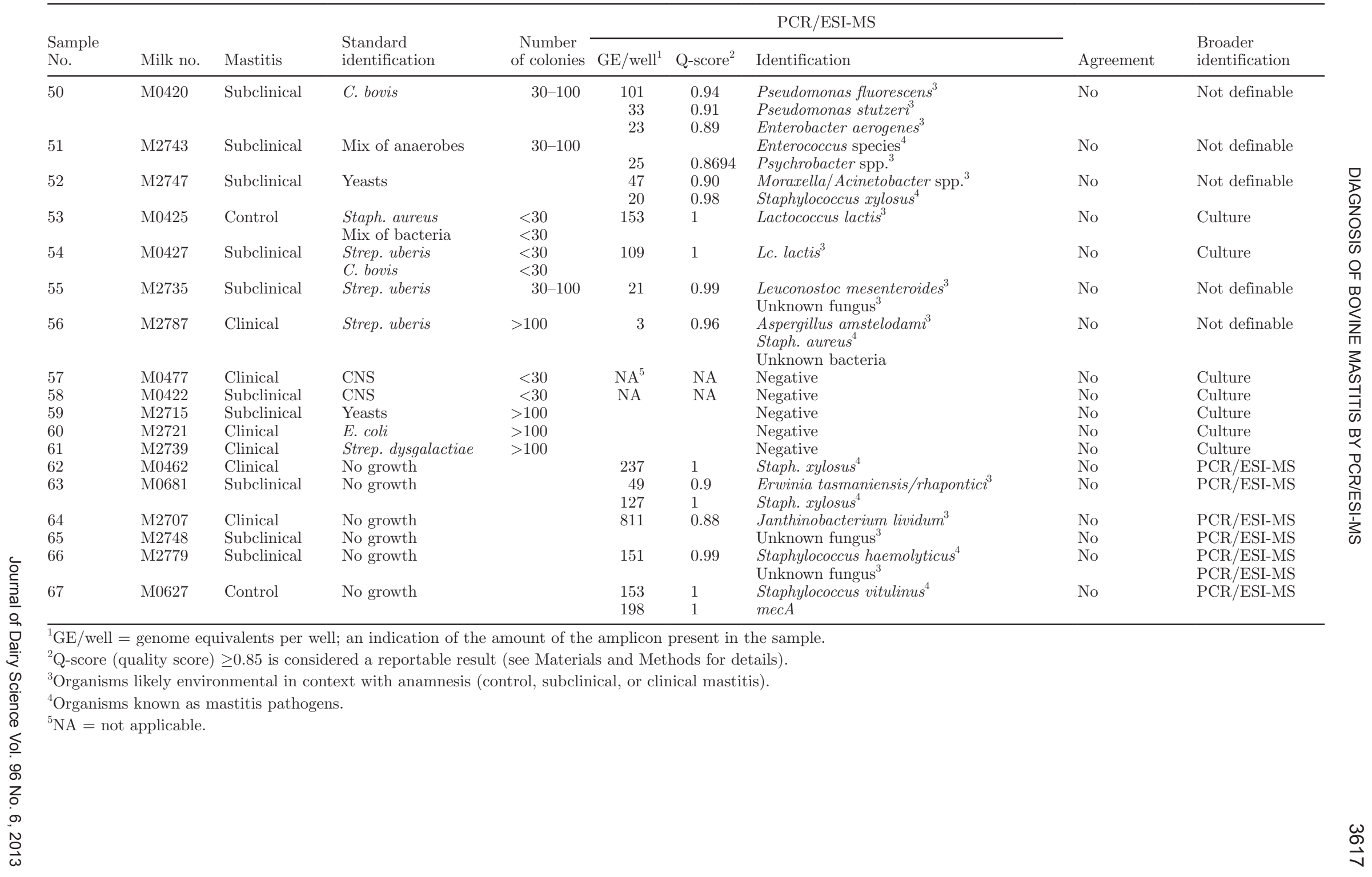


PCR/ESI-MS showed a sensitivity and specificity of 56.8 and $59.5 \%$ compared with cultures. The specificity and sensitivity increased when the detection of the pathogenic bacteria was considered individually; with $57.1 \%$ sensitivity and $96.6 \%$ specificity for Staph. aureus, $71.4 \%$ and $96.2 \%$ for streptococci, $80.0 \%$ and $69.8 \%$ for CNS, $37.5 \%$ and $96.6 \%$ for C. bovis, $75 \%$ and $93.7 \%$ for enterococci, $33.3 \%$ and $94.4 \%$ for yeasts, $66.7 \%$ and 95.3\% for Enterobacteriaceae, and 100\% sensitivity and specificity for $M$. bovis and A. pyogenes.

\section{DISCUSSION}

This is the first study that evaluates the potential of PCR/ESI-MS for veterinary microbiology diagnosis. In particular, bovine mastitis represents one of the more challenging diagnostic tasks due to the large heterogeneity of the microorganisms that may cause the disease and the permanent evolution of the disease through microbial adaptation (Bradley, 2002).

Our study demonstrates that PCR/ESI-MS appears to be a promising tool for the identification of the mastitis pathogens directly from milk using a kit developed for microbiological diagnosis in human medicine (Ecker et al., 2008). The predominant pathogen detected by PCR/ESI-MS in each sample was consistent with standard milk culture results in two-thirds of the examined samples. The PCR/ESI-MS also allowed an estimate of the relative abundance of microorganisms present in the milk samples, which may be helpful for the interpretation of the results, particularly if heterogeneity exists among the types of microorganisms present in the milk. However, the relative number of genomic copies of DNA that were amplified did not always correspond to the relative number of microorganisms estimated from the cultures, likely due to the different measurement techniques of the 2 semiquantitative methods. It should also be noted that the milk samples were sent overseas and remained room temperature for at least $1 \mathrm{wk}$, which may have allowed some contaminants to overgrow or lead to degradation of DNA from the isolates. Further validations using milk preservatives or sample refrigeration for transport are necessary before this technology can be used for diagnostic purposes.

The PCR/ESI-MS identified some of the bacteria present in highly contaminated milk, which contained more than 3 different microorganisms. However, this technology failed to identify some of the primary mastitis pathogens in $17.9 \%$ of the samples which may also be related to the prolonged transport time. Negative results of up to $12 \%$ were also reported for other PCRbased assays compared with culture (Koskinen et al., 2010). Otherwise, primary pathogens, such as Strep. uberis, Staph. aureus, Staphylococcus spp., A. pyogenes, and Mycoplasma spp., were identified. For those organisms, the sensitivity of the PCR/ESI-MS ranged from 57.1 to $100 \%$ and the specificity ranged from 69.8 to $100 \%$ using culture as gold standard. Similar ranges were obtained when PCR-based molecular methods were compared with culture (Paradis et al., 2012; Spittel and Hoedemaker, 2012). However, molecular methods have been shown to higher detection potential than culture (Koskinen et al., 2009; Koskinen et al., 2010). We also show that the rapid detection of barely cultivatable and slow-growing mastitis pathogens, such as M. bovis, by PCR/ESI-MS represents a major advantage for veterinarians in preventing the spread of the disease within respective herds (Aebi et al., 2012). Indeed, the overall workflow for PCR/ESI-MS from receipt of a sample in the laboratory to providing organism identification requires approximately $8 \mathrm{~h}$ (Wolk et al., 2012). Additionally, PCR/ESI-MS detected the presence of fungi, yeasts, and antibiotic-resistant genes. For example, Janthinobacterium lividum, an organism known to possess THIN-B, a metallo $\beta$-lactamase of class B3, was detected by PCR/ESI-MS (Docquier et al., 2004). The PCR/ESI-MS also detected the mecA gene, indicating the presence of methicillin-resistant staphylococci including methicillin-resistant Staph. aureus in bovine mastitis milk. The presence of these staphylococci in milk is a growing problem in veterinary medicine not only limiting antimicrobial treatment options, but also representing a burden for public health (Walther and Perreten, 2007; Vanderhaeghen et al., 2010; Holmes and Zadoks, 2011; Zadoks et al., 2011). Methicillin-resistant Staph. aureus present in milk may easily be transferred to humans through the consumption of raw milk or cheese (Perreten et al., 1998; Normanno et al., 2007). In this regard, PCR/ESI-MS could also find application for the direct determination of microbiological quality of bulk tank, raw milk to be used for raw milk products.

\section{CONCLUSIONS}

Our study demonstrates that PCR/ESI-MS possesses the potential to be a robust method used to screen for pathogens in the etiology of bovine mastitis. Even if the cost for analysis of a single sample on the PCR/ESI-MS system would be as high as $\$ 50$ to $\$ 100$ per sample (quoted by Wolk et al., 2012), PCR/ESI-MS has the significant advantage that it can be adapted to different settings and organisms (bacteria, mycobacteria, fungi, parasites, and viruses). The ability to perform a broad-range analysis on a variety of organism types without the need for culture or prior knowledge of the target may make the PCR/ESI-MS a more financially 
feasible option than it appears at first glance. The broad range of bacterial and fungal DNA signatures detected by PCR/ESI-MS indicates that milk may also be a reservoir of genetic elements that are important in establishing the microbial flora of an individual, which may have consequences for therapy and public health. Accomplishing these identifications in less than $6 \mathrm{~h}$, as compared with 24 to $72 \mathrm{~h}$ or longer for standard microbiological analyses, has significant implications for the dairy industry and veterinary medicine in the diagnosis of subclinical and clinical disease.

\section{ACKNOWLEDGMENTS}

This project was partially financed by Grant no. 1.11.21 of the Swiss Federal Veterinary Office (Bern, Switzerland) to V. Perreten. Research reported in this publication was supported by the National Institute of Allergy and Infectious Diseases of the National Institutes of Health (Bethesda, MD) under Award Numbers R01AI072219 and R01AI063517 to R. A. Bonomo. The content is solely the responsibility of the authors and does not necessarily represent the official views of the National Institutes of Health. The Veterans Affairs Merit Review Program and the Geriatric Research Education and Clinical Center VISN 10 (Cleveland, $\mathrm{OH}$ ) also supported R. A. Bonomo. We thank Heather Matthews, Clifford Chen, Cicely A. Washington, and Jenna Cromwell (Ibis Biosciences, Carlsbad, CA) for testing effort described in the manuscript, and Adrian Steiner (Clinic for Ruminants, Vetsuisse Faculty, University of Bern), Andrea M. Hujer, and Kristine M. Hujer (Departments of Medicine, Case Western Reserve University School of Medicine, Cleveland) for advice.

\section{REFERENCES}

Aebi, M., M. Bodmer, J. Frey, and P. Pilo. 2012. Herd-specific strains of Mycoplasma bovis in outbreaks of mycoplasmal mastitis and pneumonia. Vet. Microbiol. 157:363-368.

Ajitkumar, P., H. W. Barkema, and J. De Buck. 2012. Rapid identification of bovine mastitis pathogens by high-resolution melt analysis of $16 \mathrm{~S}$ rDNA sequences. Vet. Microbiol. 155:332-340.

Arciola, C. R., L. Montanaro, and J. W. Costerton. 2011. New trends in diagnosis and control strategies for implant infections. Int. J. Artif. Organs 34:727-736.

Barnum, D. A., and F. H. Newbould. 1961. The use of the California mastitis test for the detection of bovine mastitis. Can. Vet. J. $2: 83-90$.

Bradley, A. 2002. Bovine mastitis: An evolving disease. Vet. J. 164:116-128

Docquier, J. D., T. Lopizzo, S. Liberatori, M. Prenna, M. C. Thaller, J. M. Frère, and G. M. Rossolini. 2004. Biochemical characterization of the THIN-B metallo- $\beta$-lactamase of Janthinobacterium lividum. Antimicrob. Agents Chemother. 48:4778-4783.

Ecker, D. J., R. Sampath, C. Massire, L. B. Blyn, T. A. Hall, M. W. Eshoo, and S. A. Hofstadler. 2008. Ibis T5000: A universal biosensor approach for microbiology. Nat. Rev. Microbiol. 6:553-558.
Guélat-Brechbuehl, M., A. Thomann, S. Albini, S. Moret-Stalder, M. Reist, M. Bodmer, A. Michel, M. D. Niederberger, and T. Kaufmann. 2010. Cross-sectional study of Streptococcus species in quarter milk samples of dairy cows in the canton of Bern, Switzerland. Vet. Rec. 167:211-215.

Halasa, T., K. Huijps, O. Østerås, and H. Hogeveen. 2007. Economic effects of bovine mastitis and mastitis management: A review. Vet. Q. 29:18-31.

Hofstadler, S. A., R. Sampath, L. B. Blyn, M. W. Eshoo, T. A. Hall, Y. Jiang, J. J. Drader, J. C. Hannis, K. A. Sannes-Lowery, L. L. Cummins, B. Libby, D. J. Walcott, A. Schink, C. Massire, R. Ranken, J. Gutierrez, S. Manalili, C. Ivy, R. Melton, H. Levene, G. Barett-Wilt, F. Li, V. Zapp, N. White, V. Samant, J. A. McNeil, D. Knize, D. Robbins, K. Rudnick, A. Desai, E. Moradi, and D. J. Ecker. 2005. TIGER: The universal biosensor. Int. J. Mass Spectrom. 242:23-41.

Hogeveen, H., K. Huijps, and T. J. Lam. 2011. Economic aspects of mastitis: New developments. N. Z. Vet. J. 59:16-23.

Holmes, M. A., and R. N. Zadoks. 2011. Methicillin resistant S. aureus in human and bovine mastitis. J. Mammary Gland Biol. Neoplasia 16:373-382.

Koskinen, M. T., J. Holopainen, S. Pyörälä, P. Bredbacka, A. Pitkälä, H. W. Barkema, R. Bexiga, J. Roberson, L. Sølverød, R. Piccinini, D. Kelton, H. Lehmusto, S. Niskala, and L. Salmikivi. 2009. Analytical specificity and sensitivity of a real-time polymerase chain reaction assay for identification of bovine mastitis pathogens. J. Dairy Sci. 92:952-959.

Koskinen, M. T., G. J. Wellenberg, O. C. Sampimon, J. Holopainen, A. Rothkamp, L. Salmikivi, W. A. van Haeringen, T. J. G. M. Lam, and S. Pyörälä. 2010. Field comparison of real-time polymerase chain reaction and bacterial culture for identification of bovine mastitis bacteria. J. Dairy Sci. 93:5707-5715.

Möller, A., U. Truyen, and U. Roesler. 2007. Prototheca zopfii genotype 2: The causative agent of bovine protothecal mastitis? Vet. Microbiol. 120:370-374.

Normanno, G., M. Corrente, G. La Salandra, A. Dambrosio, N. C. Quaglia, A. Parisi, G. Greco, A. L. Bellacicco, S. Virgilio, and G. V. Celano. 2007. Methicillin-resistant Staphylococcus aureus (MRSA) in foods of animal origin product in Italy. Int. J. Food Microbiol. 117:219-222.

Paradis, M.-È., D. Haine, B. Gillespie, S. P. Oliver, S. Messier, J. Comeau, and D. T. Scholl. 2012. Bayesian estimation of the diagnostic accuracy of a multiplex real-time PCR assay and bacteriological culture for 4 common bovine intramammary pathogens. J. Dairy Sci. 95:6436-6448.

Perreten, V., N. Giampà, U. Schuler-Schmid, and M. Teuber. 1998. Antibiotic resistance genes in coagulase-negative staphylococci isolated from food. Syst. Appl. Microbiol. 21:113-120.

Rakesh, R., D. Swarup, R. Patra, and D. Nandi. 2006. Bovine protothecal mastitis: A review. CAB Rev. Perspect. Agric. Vet. Sci. Nutr. Nat. Resour. 1:17-23.

Ruegg, P. L. 2003. Investigation of mastitis problems on farms. Vet. Clin. North Am. Food Anim. Pract. 19:47-73.

Seegers, H., C. Fourichon, and F. Beaudeau. 2003. Production effects related to mastitis and mastitis economics in dairy cattle herds. Vet. Res. 34:475-491.

Spittel, S., and M. Hoedemaker. 2012. Mastitis diagnosis in dairy cows using PathoProof real-time polymerase chain reaction assay in comparison with conventional bacterial culture in a Northern German field study. Berl. Munch. Tierarztl. Wochenschr. 125:494502

Subramaniam, S., D. Bergonier, F. Poumarat, S. Capaul, Y. Schlatter, J. Nicolet, and J. Frey. 1998. Species identification of Mycoplasma bovis and Mycoplasma agalactiae based on the uvrC genes by PCR. Mol. Cell. Probes 12:161-169.

Vanderhaeghen, W., K. Hermans, F. Haesebrouck, and P. Butaye. 2010. Methicillin-resistant Staphylococcus aureus (MRSA) in food production animals. Epidemiol. Infect. 138:606-625.

Viguier, C., S. Arora, N. Gilmartin, K. Welbeck, and R. O'Kennedy. 2009. Mastitis detection: Current trends and future perspectives. Trends Biotechnol. 27:486-493. 
Walther, C., and V. Perreten. 2007. Methicillin-resistant Staphylococcus epidermidis in organic milk production. J. Dairy Sci. 90:5351.

Washington, J. A. 1996. Principles of diagnosis. Chapter 10 in Medical Microbiology. 4th ed. S. Baron, ed. University of Texas Medical Branch at Galveston, Galveston, TX.

Wellenberg, G. J., W. H. van der Poel, and J. T. Van Oirschot. 2002. Viral infections and bovine mastitis: A review. Vet. Microbiol. $88: 27-45$
Wolk, D. M., E. J. Kaleta, and V. H. Wysocki. 2012. PCR-electrospray ionization mass spectrometry: The potential to change infectious disease diagnostics in clinical and public health laboratories. J. Mol. Diagn. 14:295-304.

Zadoks, R. N., J. R. Middleton, S. McDougall, J. Katholm, and Y. H. Schukken. 2011. Molecular epidemiology of mastitis pathogens of dairy cattle and comparative relevance to humans. J. Mammary Gland Biol. Neoplasia 16:357-372. 